Finanse, Rynki Finansowe, Ubezpieczenia nr 5/2017 (89), cz. 2

DOI: $10.18276 /$ frfu. $2017.89 / 2-17$

s. $233-249$

\title{
Business Valuation - Practice of domestic WSE members in 2016
}

\author{
Piotr Adamezyk, Agnieszka Zbroszczyk ${ }^{*}$
}

\begin{abstract}
Goal - The aim of this paper is to check the popularity of various valuation methods in practice, as well as to present the statistics of parameters used in valuation processes and recommendations issued by domestic Warsaw Stock Exchange (WSE) members in the year 2016.

Methodology - The study was prepared basing on 514 valuations of 118 companies gathered from 263 recommendations issued by 8 domestic WSE members. These input data were processed using statistical tools. Finally, they were aggregated and compared with textbooks and previous studies to present final conclusions. Results - Basing on the conducted analysis, the authors stated that broadly spread opinion about high popularity of DCF and relative model in business valuation is confirmed. More interestingly, it seems that practitioners often made valuations basing on the same or very similar assumptions, which is the most visible in the adopted period of detailed analysis. It should be noted that findings are based on historical data, which do not refer to the future and apply only to companies which are listed on the stock market.

Originality - Authors' analysis provides knowledge on how domestic WSE members apply the theory of business valuation in practice, which approaches are the most commonly used, and aims at explaining to answer why it is so. This knowledge can constitute a basis for reviewing and improving valuation tools used in stock recommendations. The authors encourage to conduct further discussion regarding the practice-theory gaps, and provide data to it.
\end{abstract}

Keywords: business valuations, business valuation practice, WSE

\section{Introduction}

Contemporary Polish stock market in the form of Warsaw Stock Exchange (WSE) has been existing since the year 1991 (https://www.gpw.pl/important_dates). Currently it consists of more than 480 listed companies (https://www.gpw.pl/lista_spolek_en) and 26 domestic WSE members (https://www.gpw.pl/lista_czlonkow_gieldy_en); $96 \%$ of them are brokerage houses or banks conducting brokerage activities which, among other privileges, can issue recommendations. These analyzes are in the form of detailed reports, which include forecasts and valuations, regarding listed companies. Their goal is to support an investor with her/his investment decisions. The final element of the recommendation is the target price of a valued company. It has the strongest influence on a reader, which is why it should be calculated with the highest attention and professionalism.

\footnotetext{
*Piotr Adamczyk, MA, e-mail: piotradamczyk@hotmail.com; Agnieszka Zbroszczyk, MA, e-mail: agnieszkazbroszczyk@gmail.com.
} 
Financial industry evaluates stock brokers on a daily basis. From general point of view, analysts' skills are evaluated basing on their efficiency. Investors are interested in how much they could earn if they invested in accordance with recommendations issued (http:// www.parkiet.com/artykul/1457196.html). Less popular, but no less significant are research concerning quality of the analysis and recommendations issued (http://www.bankier.pl/ wiadomose/Ranking-domow-maklerskich-2016-DM-PKO-BP-DM-BOS-i-CDM-Pekaona-podium-7484263.html).

The concepts of value and valuation occupy a special place in the theory and practice of hundreds of thousands financial analysts. This is because they provide a way to answer the question how many units of the currency, in theory, an audited company is worth (Adamczyk, Zbroszczyk, 2017). Business valuation, in terms of brokerage houses practice, fulfills one of the basic valuation functions, which is advising in the investment process.

Analysts' results are based on their experience and knowledge. However, financial literature provides frames on which their models and valuation processes are based. The most difficult challenge is to transfer achievements of theorists to the real world and face them with the practical problems. Analysts concern which approach is the most appropriate, and how particular valuation parameters should be estimated. Theorists often have opposing opinions about many financial nuances and may run atilt for years. In such changing and developing environment practitioners have to prepare their own frameworks and processes. Many of them use the same tools differently and justify them in various ways. This is why the authors of the paper decided to prepare the study. It is crucial to know the direction in which business valuation practice is heading. The authors' aim is to find gaps between the theory and practice, and discuss the factors that cause them, as well as compare them with the previous research (Głębocki et al., 2011) in order to present how business valuation practice has changed over six years of Warsaw Stock Exchange existence.

The article consists of three main parts. The first one is a literature and practice review, which presents theorists approaches to business valuations with justification of their models and assumptions. Moreover, it regards contemporary research in stock recommendations. The second part contains research methodology, which describes statistic approaches used in the study. The third part presents research findings, which describe differences between theory and observed practice. The authors discuss those gaps and try to explain them.

\section{Literature and practice review}

Textbooks provide a whole range of possibilities to value a business. In particular, they distinguish the absolute and relative valuation approaches (Pinto et al., 2010).The first category specifies an asset's intrinsic value. It enumerates income, asset, and option-based valuation. The second category estimates an asset's value relative to another (the most similar) asset. Other approach towards company valuation is to estimate each of its divisions or business 
units as if they were independent, and sum them up. This method is called the sum-of-theparts valuation. ${ }^{1}$ Table 1 provides a brief comparison of these approaches.

\section{Table 1}

Comparison of business valuations approaches

\begin{tabular}{|c|c|c|c|}
\hline \multicolumn{3}{|c|}{ Approach } & \multirow{2}{*}{$\begin{array}{l}\text { Comment } \\
\text { - oriented on a company's historical data, } \\
\text { - used to value falling companies, and natural resource companies }\end{array}$} \\
\hline \multirow{4}{*}{ 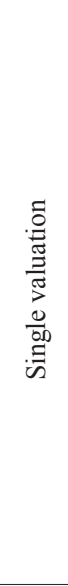 } & \multirow{3}{*}{ 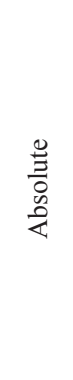 } & set-based & \\
\hline & & Income-based ${ }^{*}$ & $\begin{array}{l}\text { - oriented on a company's future potential (FCFE, FCFF, FCFC, EVA, DDM, } \\
\text { APV), } \\
\text { - requires to predict company's incomes and cost of equity/capital, } \\
\text { - is complex, } \\
\text { - requires sensitivity analysis, } \\
\text { - used to value mature going concern companies, and startups }\end{array}$ \\
\hline & & Option-based ${ }^{* *}$ & $\begin{array}{l}\text { - is the most complex (real option pricing model), } \\
\text { - for it income-based method is a starting point, } \\
\text { - used to value natural resource companies }\end{array}$ \\
\hline & 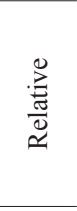 & Mark & $\begin{array}{l}\text { - requires to find peer companies, } \\
\text { - requires to know last transaction prices of peer companies or their fundamen- } \\
\text { tals, } \\
\text { - sensitive to different accounting systems and rules, } \\
\text { - can overvaluate during bull market and udervaluate during bear market, } \\
\text { - used to value companies from finance industry }\end{array}$ \\
\hline 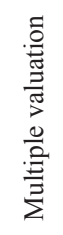 & 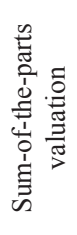 & $\begin{array}{l}\text { A mixture of } \\
\text { the single valu- } \\
\text { ation methods }\end{array}$ & $\begin{array}{l}\text { - requires to separate data for every business part which is going to be valuated, } \\
\text { - can skip the synergy effect, } \\
\text { - a special case of the sum-of-the-parts valuation is a relative valuation, which } \\
\text { peer group is divided in view of company's sectors, valued as separate ele- } \\
\text { ments, and then summed up, } \\
\text { - used to value complex corporations operating at the same time in many } \\
\text { different industries }\end{array}$ \\
\hline
\end{tabular}

"It is often limited only to "Discounted Cash Flow Model".

** It is also called "Contingent Claim Model".

Source: the authors' own proposition of division, based on Pinto et al. (2010), Damodaran (2012).

Among all valuation methods literature pay homage to the Discounted Cash Flow (DCF) model. Copeland, Koller and Murrin (1990) state that "Cash is the king", whereas Fernandez (2015b) says "Cash flow is a fact. Net income is just an opinion". With these maxims they highlight the significance of that model. However, in practice, market does not react differently depending on the valuation method used by an analyst or whether they used just one or few of them (Asquith, Mikhail, Au, 2005). According to WSE, it seems that a pure fact of issuing a recommendation is more important. Mielcarz $(2015,2016)$ proved that the share prices of companies listed on WSE tend to react strongly and as expected to both issuing

${ }^{1}$ The value obtained by using the sum-of-the-parts process is also called breakup value or private market value Pinto et al. (2010). 
of a recommendation, and the extent of deviation between the recommended prices from market prices.

It is sure that a model chosen to valuate a company exerts a tremendous influence on the obtained results. Relating to the income-based method the literature does not specify which one is the best to value a company. In addition, it states that all these methods give exactly the same result (Fernandez, 2015c; Adamczyk, Zbroszczyk, 2017), so the only difference is the aspect taken into consideration while conducting an analysis. Despite the fact that the income-based method is the one preferably given in textbooks, it should not be treated as a remedy for every financial research. Each method has its own advantages and disadvantages. However, it should be noted that the literature does not provide a simple distinction indicating which one should be used in a particular situation. In return, it gives hints to suggested models' applications. It claims that the approach to value a company depends on how marketable its assets are, whether it generates cash flows, and how unique it is in terms of its operations (Damodaran, 2012). Textbooks also state that using more than one approach can yield incremental insights (Pinto et al., 2010). Analysts try to implement this postulate by presenting their final valuation results as a range or mean. These approaches are presented and briefly compared in Table 2 .

\section{Table 2}

Ways of presenting valuation results

\begin{tabular}{|c|c|c|}
\hline Approach & & Comment \\
\hline 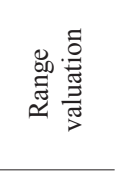 & \multirow{2}{*}{$\begin{array}{l}\text { A mixture of the } \\
\text { single valuation } \\
\text { methods and sum-of- } \\
\text {-the-parts valuation }\end{array}$} & $\begin{array}{l}\text { - requires to use at least two single or/and sum-of-the-parts valuation me- } \\
\text { thods, } \\
\text { - requires to find minimum and maximum valuation, } \\
\text { - presents a whole range covered by carried out valuations, } \\
\text { - used in fairness opinion analysis }\end{array}$ \\
\hline 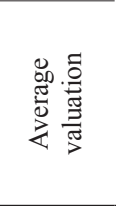 & & $\begin{array}{l}\text { - requires to use at least two single or/and sum-of-the-parts valuation me- } \\
\text { thods, } \\
\text { - requires to select and use weights of weighted mean, } \\
\text { - penultimate step is to indicate a whole range covered by carried out valu- } \\
\text { ations, } \\
\text { - used in stock recommendations }\end{array}$ \\
\hline
\end{tabular}

Source: The authors' own proposition of division, based on Pinto et al. (2010), Damodaran (2012).

\section{Research methodoloy}

There are many studies regarding the practice of business valuation, in which the answers from conducted surveys are the source of data (Bancel, Mittoo, 2014; Aguirreamalloa, Avendaño, Fernandez, 2015; Pinto et al., 2015; Fernandez, 2015a). Among many unquestionable advantages, this kind of research has one main disadvantage, which is the reliability of gathered answers. There is no chance to separate them from respondents' suppositions. Wishful 
thinking can lead an analyst to answer in a different way than he would act in reality. This is why this paper's authors decided to base their research on the recommendations issued. They include documents in which decisions regarding an analysis were made, and bring effects on investors. In reference to the Polish stock market this approach was used by Głębocki et al. (2011). They examined 224 recommendations issued between January 1 and September 30, 2010. After 6 years of valuations made by the members of the Polish stock market for the purposes of this article, their study is treated as a point of reference and data source to compare the research results.

Since December 31, 2016, 26 domestic WSE members have operated on the Warsaw Stock Exchange. 25 (96\%) of them had a permission to issue recommendations. Some of them issued their analysis only to corporate clients or for internal use, giving into the public only the estimated target price with short comment. Taking into account the aspects discussed above, the authors chose the following conditions to select the research sample:

1. Recommendations were issued by the Warsaw Stock Exchange (WSE) members, which:

- are domestic brokerage houses or banks conducting brokerage activities licensed by the Polish Financial Supervision Authority (KNF), and,

- have a permission to issue recommendations. ${ }^{2}$

2. Recommendations were prepared in $2016 .^{3}$

3. The companies valued were not banks. ${ }^{4}$

4. Reports include full information about valuation method/s. ${ }^{5}$

Tables 3 and 4 present the distribution of chosen research sample.

The final size of the research sample, which meets the accepted requirements, consist of 514 valuations of 118 companies, which come from 263 recommendations issued by 8 domestic WSE members (32\% of all domestic WSE members permitted to issue recommendations).

\footnotetext{
${ }^{2}$ To issue a recommendation a brokerage house or bank conducting brokerage activities must have permission granted by the Polish Financial Supervision Authority, as results from the Trading in Financial Instruments Act. (https://www.knf.gov.pl/en/about_the_market/Capital_market/entities/entities.html, http://isap.sejm.gov.pl/ DetailsServlet?id=WDU20051831538).

${ }^{3}$ Date of issuance can be different.

${ }^{4}$ Because of banks special character, the authors decided that they should be an object of individual research, and did not include them in this study.

${ }^{5}$ Due to the lack of necessary information about valuation methods, "one-page recommendations" (which are often updates) were not included in the performed study. The authors took into consideration only detailed reports which include valuations findings, and at least made assumptions.
} 
Table 3

Number of recommendations issued by 8 domestic WSE members

\begin{tabular}{llcc}
\hline No. & WSE member name & Recommendations & Weight (\%) \\
\hline 1. & DOM MAKLERSKI BDM SA & 68 & 25.9 \\
2. & DOM MAKLERSKI MBANKU SA & 56 & 21.3 \\
3. & PKO BANK POLSKI SA & 52 & 19.8 \\
4. & BANK ZACHODNI WBK SA & 51 & 19.4 \\
5. & VESTOR DOM MAKLERSKI SA & 17 & 6.5 \\
6. & DOM MAKLERSKI BANKU BPS SA & 9 & 3.4 \\
7. & BANK BGŻ BNP PARIBAS SA & 5 & 1.9 \\
8. & MILLENNIUM DOM MAKLERSKI SA & 5 & 1.9 \\
\hline & $\Sigma$ & 263 & 100.0 \\
\hline
\end{tabular}

Source: the authors' own derivation.

Table 4

Amount of issued recommendations per sector

\begin{tabular}{rlcr}
\hline No. & Sector & \multicolumn{2}{c}{ Frequency $(\%)$} \\
\hline 1. & Construction & 27 & 10.3 \\
2. & Clothes \& cosmetics & 25 & 9.5 \\
3. & Real estate & 22 & 8.4 \\
4. & Oil \& gas & 20 & 7.6 \\
5. & Chemicals & 18 & 6.8 \\
6. & IT & 17 & 6.5 \\
7. & Metallurgy & 13 & 4.9 \\
8. & Telecom & 13 & 4.9 \\
9. & Mining & 11 & 4.2 \\
10. & Leisure Facilities & 9 & 3.4 \\
11. & Media & 8 & 3.0 \\
12. & Others (each $<3.0 \%)$ & 80 & 30.4 \\
\hline & $\Sigma$ & 263 & 100.0 \\
\hline
\end{tabular}

Source: the authors' own derivation.

Figure 1 presents the multiplicity of recommendations because some companies were recommended more often, and some less frequently. For instance, during 2016, 58 companies were recommended once and it was the most common case (49.2\%). The second highest rate was $19.5 \%$, where each of 23 companies were recommended twice. 


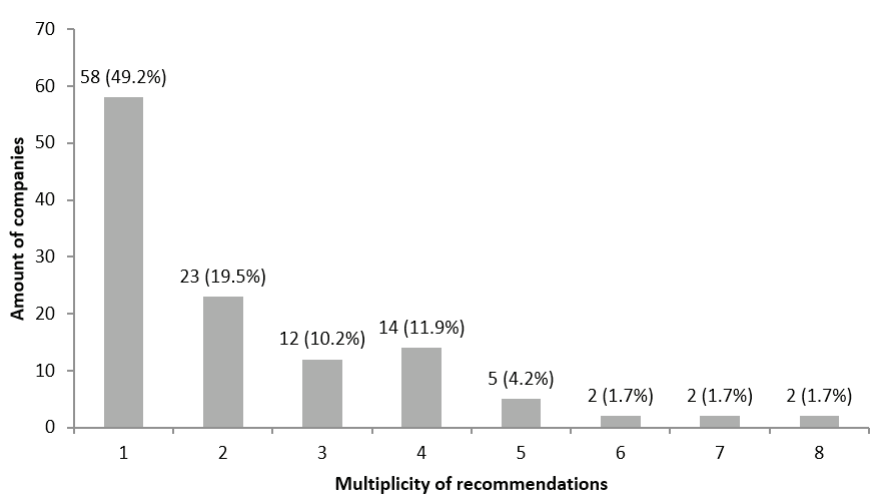

Figure 1. Multiplicity of prepared recommendations

Source: the authors' own derivation.

In order to make inferences, the authors processed the data gathered using basic statistics, as range, arithmetic mean, median, and standard deviation. Research results were compared with the literature released until 2015, so that the WSE members had the chance to take advantage of its achievements in the year 2016. Moreover, the authors compare ${ }^{6}$ their findings with the results obtained by Głębocki et al. (2011) to identify changes in practice of the WSE participants in terms of business valuations.

\section{Research findings and discussion}

263 recommendations contain 514 valuations. Tables 5 and 6 present the amount and types of valuation methods applied in recommendations. Two valuation methods were applied most frequently (93.2\%), and the most popular among them was a combination of the market-based and income-based approach (86.7\%). In 2010, 98.7\% recommendations were made using two methods, and in $97.8 \%$ cases the same methods as in 2016 were applied. It is in compliance with textbooks which encourage to use more than only one method. If they are considered separately, the most popular was the market-based and the income-based approach, they were used in $248(48.2 \%)$ and 242 (47.1\%) recommendations, respectively. The $\mathrm{STOP}^{7}$ approach was used in 21 (4.1\%) recommendations, while the asset-based approach was used only in $3(1.1 \%)$ recommendations. The SOTP valuation consist of the income-based, market-based, and asset-based approaches mixture, which is presented in Table 7 and 8 . The option-based method was not put into practice in the examined period.

\footnotetext{
${ }^{6}$ Where it was possible.

${ }^{7}$ SOTP method was most popularly (33.3\%) used to value companies from real estate sector.
} 
Table 5

The frequency of valuation approach sets used in recommendations

\begin{tabular}{|c|c|c|c|c|c|c|c|c|c|c|c|c|c|}
\hline \multirow{2}{*}{$\begin{array}{l}\text { Valuations per } \\
\text { recommendation }\end{array}$} & \multirow{2}{*}{\multicolumn{2}{|c|}{$\begin{array}{l}\text { Recommenda- } \\
\text { tions frequency } \\
\text { level I }\end{array}$}} & \multirow{2}{*}{\multicolumn{2}{|c|}{$\begin{array}{l}\text { Valuations } \\
\text { frequency } \\
\text { level I } \\
\end{array}$}} & \multicolumn{3}{|c|}{ Absolute $^{*}$} & \multirow{3}{*}{ MB } & \multirow{3}{*}{ SOTP } & \multirow{2}{*}{\multicolumn{2}{|c|}{$\begin{array}{l}\text { Recommenda- } \\
\text { tions frequen- } \\
\text { cy level II }\end{array}$}} & \multirow{2}{*}{\multicolumn{2}{|c|}{$\begin{array}{l}\text { Valuations } \\
\text { frequency } \\
\text { level II } \\
\end{array}$}} \\
\hline & & & & & $\mathrm{AB}$ & IB & OB & & & & & & \\
\hline \multirow{5}{*}{1} & \multirow{5}{*}{15} & \multirow{5}{*}{$5.7 \%$} & \multirow{5}{*}{15} & \multirow{5}{*}{$2.9 \%$} & \multirow[t]{5}{*}{$\mathrm{x}$} & & & & & 0 & $0.0 \%$ & 0 & $0.0 \%$ \\
\hline & & & & & & $\mathrm{x}$ & & & & 11 & $4.2 \%$ & 11 & $2.1 \%$ \\
\hline & & & & & & & $\mathrm{x}$ & & & 0 & $0.0 \%$ & 0 & $0.0 \%$ \\
\hline & & & & & & & & $\mathrm{x}$ & & 0 & $0.0 \%$ & 0 & $0.0 \%$ \\
\hline & & & & & & & & & $\mathrm{x}$ & 4 & $1.5 \%$ & 4 & $0.8 \%$ \\
\hline \multirow{3}{*}{2} & \multirow{3}{*}{245} & \multirow{3}{*}{$93.2 \%$} & \multirow{3}{*}{490} & \multirow{3}{*}{$95.3 \%$} & & $\mathrm{x}$ & & $\mathrm{x}$ & & 228 & $86.7 \%$ & 456 & $88.7 \%$ \\
\hline & & & & & & & & $\mathrm{x}$ & $\mathrm{x}$ & 14 & $5.3 \%$ & 28 & $5.5 \%$ \\
\hline & & & & & $\mathrm{x}$ & & & $\mathrm{x}$ & & 3 & $1.1 \%$ & 6 & $1.2 \%$ \\
\hline 3 & 3 & $1.1 \%$ & 9 & $1.8 \%$ & & $\mathrm{x}$ & & $\mathrm{x}$ & $\mathrm{x}$ & 3 & $1.1 \%$ & 9 & $1.8 \%$ \\
\hline$\Sigma$ & 263 & $100.0 \%$ & 514 & $100.0 \%$ & & & & & $\Sigma$ & 263 & $100.0 \%$ & 514 & $100.0 \%$ \\
\hline
\end{tabular}

${ }^{*}$ Abbreviations from Table 7.

Source: the authors' own derivation.

Table 6

The frequency of valuation approaches used in recommendations

\begin{tabular}{|c|c|c|c|c|c|c|c|c|}
\hline Level I & & & Level II & & & Level III & & \\
\hline \multirow{4}{*}{ Single } & \multirow{4}{*}{493} & \multirow{4}{*}{$95.9 \%$} & \multirow{3}{*}{ Absolute } & \multirow{3}{*}{245} & \multirow{3}{*}{$47.7 \%$} & Income-based & 242 & $47.1 \%$ \\
\hline & & & & & & Asset-based & 3 & $0.6 \%$ \\
\hline & & & & & & Option-based & 0 & $0.0 \%$ \\
\hline & & & Relative & 248 & $48.2 \%$ & Market-based & 248 & $48.2 \%$ \\
\hline Multiple & 21 & $4.1 \%$ & SOTP & 21 & $4.1 \%$ & SOTP & 21 & $4.1 \%$ \\
\hline$\Sigma$ & 514 & $100.0 \%$ & $\Sigma$ & 514 & $100.0 \%$ & $\Sigma$ & 514 & $100.0 \%$ \\
\hline
\end{tabular}

Source: the authors' own derivation.

\section{Table 7}

The frequency of valuation approaches used in SOTP valuation ${ }^{8}$

\begin{tabular}{lll}
\hline Approach & Frequency & \\
\hline Income-based (IB) & 13 & $61.9 \%$ \\
Market-based (MB) & 12 & $57.1 \%$ \\
Asset-based (AB) & 11 & $52.4 \%$ \\
Exit Yield (EY) & 3 & $14.3 \%$ \\
Option-based (OB) & 0 & $0.0 \%$ \\
\hline
\end{tabular}

Source: the authors' own derivation.

${ }^{8}$ Analysts also used a method which they called the "Exit Yield". It is used in the income-based valuation, and represents the value of the investment property at the end of the analysis period (exit value), expressed as percentages. The exit value is the net amount which an entity expects to obtain for an asset at the end of the analysis period, after the deduction of expected disposal costs (in this sense, exit value is similar to residual value). 


\section{Table 8}

The frequency of valuation approach sets used in SOTP valuation

\begin{tabular}{lcc}
\hline Approach set $^{*}$ & Frequency & \\
\hline $\mathrm{IB}$ & 5 & $23.8 \%$ \\
$\mathrm{IB}+\mathrm{MB}$ & 4 & $19.0 \%$ \\
$\mathrm{AB}+\mathrm{MB}+\mathrm{IB}$ & 4 & $19.0 \%$ \\
$\mathrm{AB}$ & 3 & $14.3 \%$ \\
$\mathrm{AB}+\mathrm{EY}+\mathrm{MB}$ & 2 & $9.5 \%$ \\
$\mathrm{MB}$ & 1 & $4.8 \%$ \\
$\mathrm{AB}+\mathrm{EY}$ & 1 & $4.8 \%$ \\
$\mathrm{AB}+\mathrm{MB}$ & 1 & $4.8 \%$ \\
\hline$\Sigma$ & 21 & $100.0 \%$ \\
\hline
\end{tabular}

${ }^{*}$ Abbreviations from Table 7.

Source: the authors' own derivation.

Because of a special character of stock recommendations, which are supposed to determine a target price, range type of valuation was not used at all. Instead, average type of valuation was used in each of them, sometimes (36.9\%) even with $0 \%$ weight of one of the applied methods. ${ }^{9}$

\subsection{Absolute valuation}

Tables 9 and 10 show that relating to the income-based valuation in the tested sample a method based on Discounted Cash Flow with Free Cash Flow to Firm occurred most frequently (98.8\%). It is similar to the results obtained in 2010, when this method was used very often as well $(84.0 \%)$. The literature tries not to exalt this method among other types of cash flows or even incomes. However, when textbooks describe the income-based valuation model they often present it as the main method.

\section{Table 9}

The frequency of income types used in income-based valuations

\begin{tabular}{lcr}
\hline Income type & Frequency & \\
\hline FCFF & 239 & $98.8 \%$ \\
DIV & 10 & $4.1 \%$ \\
RI & 4 & $1.7 \%$ \\
FCFE & 0 & $0.0 \%$ \\
FCFC & 0 & $0.0 \%$ \\
EVA & 0 & $0.0 \%$ \\
TS & 0 & $0.0 \%$ \\
\hline
\end{tabular}

Source: the authors' own derivation.

${ }^{9}$ Justification of it is usually only a statement that the chosen method remains an analyst's primary valuation tool, this is why it amounts to $100 \%$ in determining the target price. 


\section{Table 10}

The frequency of income type sets used in income-based valuations

\begin{tabular}{lcc}
\hline Income set & Frequency & \\
\hline FCFF & 230 & $95.0 \%$ \\
FCFF + DIV & 8 & $3.3 \%$ \\
RI & 2 & $0.8 \%$ \\
FCFF + DIV + RI & 1 & $0.4 \%$ \\
RI + DIV & 1 & $0.4 \%$ \\
FCFF + RI & 0 & $0.0 \%$ \\
DIV & 0 & $0.0 \%$ \\
\hline$\Sigma$ & 242 & $100.0 \%$ \\
\hline
\end{tabular}

Source: the authors' own derivation.

Income should be discounted by an appropriate discount rate. Each recommendation studied declared that it used the right one. Doubts arouse when it comes to a company's future capital structure. Table 11 presents approaches to WACC weights used by each of the examined recommendations issued by chosen WSE participants', whereas Table 12 shows how many WACC were constant or variable. In 2010, $68.0 \%$ of them were variable, and $85.6 \%$ did not contain any justification of the accepted discount rates. In $2016,68.0 \%$ of them were variable. Analysts again did not clearly state how they estimated discount rates, but basing on tables included in reports the authors noticed that in order to estimate cost of equity CAPM was used most frequently, whereas in order to estimate company's future capital structure which is used in WACC each WSE member had their own guideline. Unfortunately, they were indicated without any explanation. This is why their approaches cannot be directly compared with the contemporary literature and previous research. There were 3 recommendations, in which only direct method was used (two with RI and one with RI + DIV), and WACC weights were not presented.

\section{Table 11}

Approaches to estimation of WACC weights

\begin{tabular}{ll}
\hline Approach & WSE members \\
\hline Debt / (Debt + Equity) & 6 \\
Net debt / (Net debt + Market Capitalization) & 1 \\
Debt / Capital & 1 \\
\hline
\end{tabular}

Source: the authors' own derivation. 
Table 12

WACC weights

\begin{tabular}{lcrlrc}
\hline Valuation process & Frequency & & WACC weights & Frequency \\
\hline \multirow{3}{*}{ At least sequential } & 239 & \multirow{2}{*}{$98.8 \%$} & Variable & 164 & $67.8 \%$ \\
& & & Fixed & 50 & $20.7 \%$ \\
& & No info. & 25 & $10.3 \%$ \\
\hline Only direct & $1.2 \%$ & No info. & 3 & $1.2 \%$ \\
\hline$\Sigma$ & 242 & $100.0 \%$ & $\Sigma$ & 242 & $100.0 \%$ \\
\hline
\end{tabular}

Source: the authors' own derivation.

Each income-based valuation consisted of a two-stage model. In few WSE members standardization of detailed analysis period was very visible, as presented by Figure 2. It usually contains of 10 periods, and it was the same as in 2010, when a ten-year period was also the most popular one (68.2\%). That kind of unification is not in compliance with the literature, which states that each time a detailed analysis period should be designated individually.

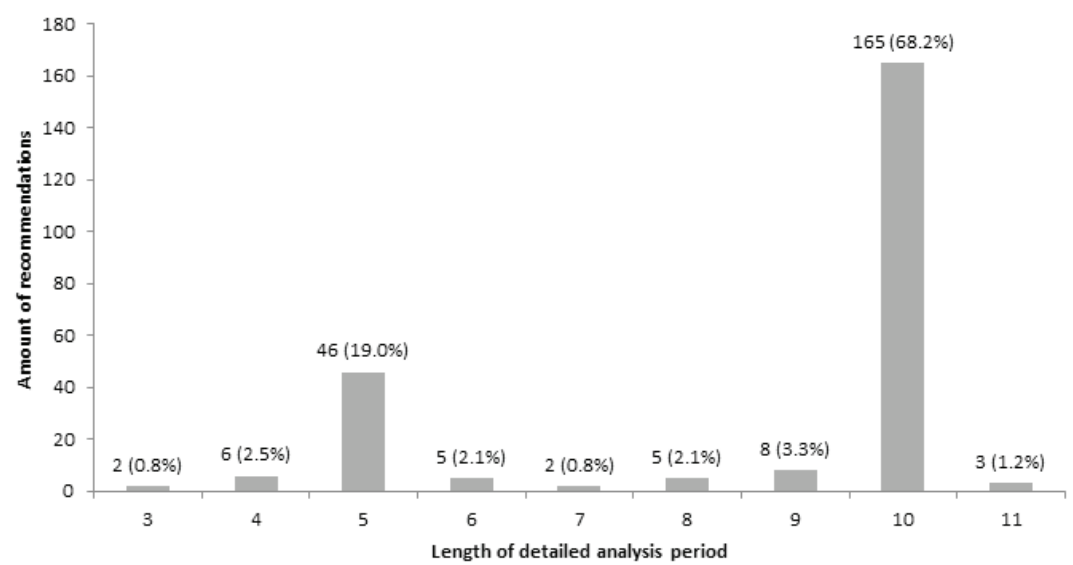

Figure 2. Detailed analysis period length

Source: the authors' own derivation.

In almost every examined recommendation $(97.3 \%, 256$ reports) analysts presented a historical and estimated financial statement, and compared them using a ratio analysis. There were noted not very high rate of sensitivity analysis occurrence (79.8\%), which is thoroughly presented in Table 13. The literature encourages to prepare and present a sensitivity analysis, and treats it as the best market practice. 


\section{Table 13}

The frequency of sensitivity analysis sets used in income-based valuations

\begin{tabular}{|c|c|c|c|c|c|c|c|c|}
\hline \multicolumn{3}{|c|}{ Frequency level I } & \multicolumn{3}{|c|}{ Frequency level II } & \multicolumn{3}{|l|}{ Frequency level III } \\
\hline \multirow{12}{*}{ Occurs } & \multirow{12}{*}{193} & \multirow{12}{*}{$79.8 \%$} & \multirow{8}{*}{$\begin{array}{l}1 \text { sensitivity } \\
\text { analys }\end{array}$} & \multirow{8}{*}{126} & \multirow{8}{*}{$52.1 \%$} & $\mathrm{~g} /$ Discount rate & 105 & $43.4 \%$ \\
\hline & & & & & & $\mathrm{g} /$ Risk-free rate & 13 & $5.4 \%$ \\
\hline & & & & & & $\begin{array}{l}\text { Copper price/Currency exchange } \\
\text { rate }\end{array}$ & 3 & $1.2 \%$ \\
\hline & & & & & & $\mathrm{g} /$ EBIT margin & 2 & $0.8 \%$ \\
\hline & & & & & & $\mathrm{MRP} / \mathrm{g}$ & 1 & $0.4 \%$ \\
\hline & & & & & & $\mathrm{g} /$ Coal price & 1 & $0.4 \%$ \\
\hline & & & & & & BETA/g & 1 & $0.4 \%$ \\
\hline & & & & & & MRP/BETA & 0 & $0.0 \%$ \\
\hline & & & \multirow{3}{*}{$\begin{array}{l}2 \text { sensitivity } \\
\text { analysis }\end{array}$} & \multirow{3}{*}{11} & \multirow{3}{*}{$4.6 \%$} & BETA/g + g/Discount rate & 5 & $2.1 \%$ \\
\hline & & & & & & $\mathrm{MRP} / \mathrm{BETA}+\mathrm{g} /$ Risk-free rate & 4 & $1.7 \%$ \\
\hline & & & & & & $\mathrm{g} /$ Discount rate $+\mathrm{g} /$ Risk-free rate & 2 & $0.8 \%$ \\
\hline & & & $\begin{array}{l}\text { sensitivity } \\
\text { analysis }\end{array}$ & 56 & $23.1 \%$ & $\mathrm{BETA} / \mathrm{g}+\mathrm{MRP} / \mathrm{g}+\mathrm{MRP} / \mathrm{BETA}$ & 56 & $23.1 \%$ \\
\hline $\begin{array}{l}\text { Does not } \\
\text { occur }\end{array}$ & 49 & $20.2 \%$ & - & 49 & $20.2 \%$ & - & 49 & $20.3 \%$ \\
\hline$\Sigma$ & 242 & $100.0 \%$ & $\Sigma$ & 242 & $100.0 \%$ & $\Sigma$ & 242 & $100.0 \%$ \\
\hline
\end{tabular}

Source: the authors' own derivation.

\subsection{Relative valuation}

The examined market-based valuations usually (69.8\%) used two multipliers (Table 19), which were $\mathrm{P} / \mathrm{E}(90.7 \%)$ and $\mathrm{EV} / \mathrm{EBITDA}(90.2 \%)$. It is in compliance with the literature, which encourages to value a company basing on more than one multiplier, and more than one type of multipliers. Statistics are almost the same as they were in 2010, when P/E was used in $93 \%$, and EV/EBITDA in $95 \%$ of relative valuations. A detailed distribution of the applied multipliers is presented in Table 14 and Table 15.

Analysts used estimated multipliers (90.7\%) most frequently, which were based on market and book values. However, a research sample also consists of multipliers based on income valuation, especially in case of the $\mathrm{P} / \mathrm{BV}$ multiplier ${ }^{10}$. High rate of estimated multipliers used in valuation is in compliance with the literature, which states that the valuation should be a forward looking process. In 2010, 76\% of valuations used estimated multipliers. Table 16 presents details regarding a type of multiplier used, and its frequency of application.

\footnotetext{
${ }^{10}$ This method is called there the "The warranted equity method" (WEV) and is based on the P/BV formula = (forward ROE less sustainable growth rate)/(Cost of equity less sustainable growth rate).
} 


\section{Table 14}

The frequency of multipliers sets used in market-based valuations

\begin{tabular}{|c|c|c|c|c|c|}
\hline $\begin{array}{l}\text { Multipliers } \\
\text { per valuation }\end{array}$ & $\begin{array}{l}\text { Frequency } \\
\text { level I }\end{array}$ & & Multipliers set & $\begin{array}{l}\text { Frequency } \\
\text { level II }\end{array}$ & \\
\hline \multirow{2}{*}{1} & \multirow{2}{*}{20} & \multirow{2}{*}{$8.1 \%$} & EV/EBITDA & 13 & $5.2 \%$ \\
\hline & & & $\mathrm{P} / \mathrm{BV}$ & 7 & $2.8 \%$ \\
\hline \multirow{5}{*}{2} & \multirow{5}{*}{173} & \multirow{5}{*}{$69.7 \%$} & $\mathrm{P} / \mathrm{E}+\mathrm{EV} / \mathrm{EBITDA}$ & 155 & $62.5 \%$ \\
\hline & & & $\mathrm{P} / \mathrm{E}+\mathrm{P} / \mathrm{BV}$ & 13 & $5.2 \%$ \\
\hline & & & $\mathrm{P} / \mathrm{E}+\mathrm{ROE}-\mathrm{P} / \mathrm{BV}$ & 2 & $0.8 \%$ \\
\hline & & & EV/EBITDA + DY & 2 & $0.8 \%$ \\
\hline & & & $\mathrm{EV} / \mathrm{EBITDA}+\mathrm{EV} / \mathrm{FCF}$ & 1 & $0.4 \%$ \\
\hline \multirow{6}{*}{3} & \multirow{6}{*}{54} & \multirow{6}{*}{$21.8 \%$} & $\mathrm{P} / \mathrm{E}+\mathrm{EV} / \mathrm{EBITDA}+\mathrm{EV} / \mathrm{EBIT}$ & 30 & $12.1 \%$ \\
\hline & & & $\mathrm{P} / \mathrm{E}+\mathrm{EV} / \mathrm{EBITDA}+\mathrm{DY}$ & 13 & $5.2 \%$ \\
\hline & & & $\mathrm{P} / \mathrm{E}+\mathrm{EV} / \mathrm{EBITDA}+\mathrm{P} / \mathrm{CE}$ & 4 & $1.6 \%$ \\
\hline & & & $\mathrm{P} / \mathrm{E}+\mathrm{EV} / \mathrm{EBITDA}+\mathrm{PEG}$ & 3 & $1.2 \%$ \\
\hline & & & $\mathrm{P} / \mathrm{E}+\mathrm{P} / \mathrm{BV}+\mathrm{ROE}-\mathrm{P} / \mathrm{BV}$ & 2 & $0.8 \%$ \\
\hline & & & $\mathrm{P} / \mathrm{BV}+\mathrm{ND} / \mathrm{E}+\mathrm{PEG}$ & 2 & $0.8 \%$ \\
\hline 4 & 1 & $0.4 \%$ & $\mathrm{P} / \mathrm{E}+\mathrm{EV} / \mathrm{EBITDA}+\mathrm{ND} / \mathrm{E}+\mathrm{DY}$ & 1 & $0.4 \%$ \\
\hline$\Sigma$ & 248 & $100.0 \%$ & $\Sigma$ & 248 & $100.0 \%$ \\
\hline
\end{tabular}

Source: the authors' own derivation.

\section{Table 15}

The frequency of multipliers used in market-based valuations

\begin{tabular}{lcc}
\hline Multiplier & Frequency & \\
\hline P/E & 223 & $90.7 \%$ \\
EV/EBITDA & 222 & $90.2 \%$ \\
EV/EBIT & 30 & $12.2 \%$ \\
P/BV & 24 & $9.8 \%$ \\
DY & 16 & $6.5 \%$ \\
PEG & 5 & $2.0 \%$ \\
ROE-P/BV & 4 & $1.6 \%$ \\
P/CE & 4 & $1.6 \%$ \\
ND/E & 3 & $1.2 \%$ \\
EV/FCF & 1 & $0.4 \%$ \\
\hline
\end{tabular}

Source: the authors' own derivation. 
Table 16

Multipliers in the context of their time perspective

\begin{tabular}{|c|c|c|c|c|c|}
\hline \multirow[t]{2}{*}{ Multipliers } & \multicolumn{2}{|c|}{ Frequency level I } & \multirow{2}{*}{$\begin{array}{l}\text { Periods } \\
1\end{array}$} & \multicolumn{2}{|c|}{ Frequency level II } \\
\hline & \multirow{4}{*}{225} & \multirow{4}{*}{$90.7 \%$} & & 0 & $0.0 \%$ \\
\hline \multirow{3}{*}{ Estimated (E) } & & & 2 & 24 & $9.7 \%$ \\
\hline & & & 3 & 200 & $80.6 \%$ \\
\hline & & & 4 & 1 & $0.4 \%$ \\
\hline \multirow{2}{*}{$\begin{array}{l}\text { Historical + } \\
\text { Estimated }\end{array}$} & \multirow{2}{*}{18} & \multirow{2}{*}{$7.3 \%$} & $1 \mathrm{H}+1 \mathrm{E}$ & 1 & $0.4 \%$ \\
\hline & & & $1 \mathrm{H}+2 \mathrm{E}$ & 17 & $6.9 \%$ \\
\hline \multirow{3}{*}{ Historical (H) } & \multirow{3}{*}{5} & \multirow{3}{*}{$2.0 \%$} & 1 & 4 & $1.6 \%$ \\
\hline & & & 2 & 0 & $0.0 \%$ \\
\hline & & & 3 & 1 & $0.4 \%$ \\
\hline$\Sigma$ & 248 & $100.0 \%$ & $\Sigma$ & 248 & $100.0 \%$ \\
\hline
\end{tabular}

Source: the authors' own derivation.

Relative valuations used a wide range of comparatives, not only in terms of their number but also a form of their division. The authors noticed two types of peers' division: ${ }^{11}$ per peers' localizations $(19.0 \%)$, and per sectors (14.1\%). In the case when peers were not divided, they referred to the whole company, and it was the most popular case $(64.1 \%)$. Detailed data are presented in Table 17 and Table 18.In this field, the research from 2010 was incomplete.

\section{Table 17}

Distribution of peers used in relative valuations

\begin{tabular}{llcc}
\hline Point of reference & & Frequency & \\
\hline \multirow{2}{*}{ Based on comparables } & Whole company & 159 & $64.1 \%$ \\
& Localization & 47 & $19.0 \%$ \\
& Sector & 35 & $14.1 \%$ \\
& No info. & 5 & $2.0 \%$ \\
\hline Based on fundamentals* & & 2 & $0.8 \%$ \\
\hline$\Sigma$ & & 248 & $100.0 \%$ \\
\hline
\end{tabular}

"Two valuations were made using the "Warranted equity method".

Source: the authors' own derivation.

${ }^{11}$ It is worth to note that peers divided per localization or not divided at all are processed as standard market-based valuation, whereas in the case when peers were divided per valued company's sectors, the analysis is processed as the SOTP valuation, when in each case relative valuation was used. 


\section{Table 18}

Distribution of peers used in relative valuations

\begin{tabular}{|c|c|c|c|c|c|c|c|c|c|c|}
\hline \multirow[b]{3}{*}{ Company } & \multirow{2}{*}{\multicolumn{2}{|c|}{$\begin{array}{l}\text { Recommenda- } \\
\text { tions frequency }\end{array}$}} & \multirow{3}{*}{$\begin{array}{l}\begin{array}{l}\text { Locali- } \\
\text { zation or } \\
\text { sectors }\end{array} \\
-\end{array}$} & \multirow{2}{*}{\multicolumn{2}{|c|}{$\begin{array}{l}\text { Recommendations } \\
\text { frequency }\end{array}$}} & \multicolumn{5}{|l|}{ Peers } \\
\hline & & & & & & Min. & Max. & $\begin{array}{l}\text { Arith- } \\
\text { metic }\end{array}$ & Median & Standard \\
\hline & 159 & $64.6 \%$ & & 159 & $64.6 \%$ & 2.0 & 29.0 & 10.7 & 10.0 & 5.5 \\
\hline \multirow{4}{*}{$\begin{array}{l}\text { Localiza- } \\
\text { tion }\end{array}$} & \multirow{4}{*}{47} & \multirow{4}{*}{$19.1 \%$} & 2 & 38 & $15.5 \%$ & 8.0 & 28.0 & 16.7 & 16.0 & 4.5 \\
\hline & & & 3 & 6 & $2.4 \%$ & 17.0 & 26.0 & 22.2 & 23.5 & 3.9 \\
\hline & & & 5 & 2 & $0.8 \%$ & 16.0 & 16.0 & 16.0 & 16.0 & 0.0 \\
\hline & & & 7 & 1 & $0.4 \%$ & 18.0 & 18.0 & 18.0 & 18.0 & 0.0 \\
\hline \multirow{3}{*}{ Sector } & \multirow{3}{*}{35} & \multirow{3}{*}{$14.2 \%$} & 2 & 29 & $11.8 \%$ & 6.0 & 24.0 & 15.3 & 16.0 & 5.6 \\
\hline & & & 3 & 4 & $1.6 \%$ & 19.0 & 36.0 & 27.0 & 26.5 & 7.6 \\
\hline & & & 4 & 2 & $0.8 \%$ & 14.0 & 36.0 & 25.0 & 25.0 & 11.0 \\
\hline No info. & 5 & $2.0 \%$ & - & 5 & $2.0 \%$ & - & - & - & - & - \\
\hline$\Sigma$ & $246^{*}$ & $100.0 \%$ & & $246^{*}$ & $100.0 \%$ & & & & & \\
\hline
\end{tabular}

The most popular averaging statistic was a median, which was used in $93.5 \%$ of cases, an arithmetic mean was used in $3.3 \%$ of cases, whereas in the remaining $3.3 \%$ of cases there was a lack of information about the applied statistic. In the process of the market-based valuation equity value can be calculated even per each peer, but most often it is a result of averaging. Due to insufficient data regarding detailed inference the authors could only enumerate elements which took part in the averaging process. They were multipliers types, forecast periods, and localizations. In addition, analysts were averaging on many different levels.

\section{Conclusions}

Domestic WSE members issue recommendations to fulfill advisory function. They generally use two valuation approaches, and average them. These approaches usually include the income-based and market-based single valuation. Analysts most frequently use an arithmetic mean, but there are also situations when weighted mean is used, even with $0 \%$ weight of some valuation. Unfortunately, the assumed weights are usually just statements without any justification.

Because of the advisory function, reports made by domestic WSE members should be understandable for an investor. This is why the highest popularity of relative valuation is not a surprise. This approach is broadly considered as simple to carry and easy to understand. The income-based DCF model may seem to be more difficult to understand. Despite that, recommendations do not always include detailed justifications of its assumptions. One-page recommendations with only brief reference to models used in valuation constitute the most 
extreme cases. Following this reasoning process, it is no surprise that the option-based approach was not used at all. However, intelligibility of recommendations cannot be the reason of limiting investment tools or limiting presented data.

In terms of income-based valuation, Free Cash Flows to Firm are used most frequently, and they are always discounted by a proper discount rate - WACC. As regards to cost of equity, analysts usually use the CAPM to estimate it. Relating to the market-based valuation, it was proved that since the publication of "Security analysis" by Dodd \& Graham (1934) P/E is still the most popular multiplier. Moreover, analysts use EV/EBITDA multiplier almost equally often. Because of considering valuation process from forward looking perspective, they used estimated multipliers most often for three consecutive years. All of the findings mentioned before are in compliance with the theory included in textbooks, but the authors noticed also some incompatibilities.

After studying 263 recommendations, the authors realized that many valuations parameters look similar. This issue is strongly visible in the period of a detailed analysis of issued recommendations. Most of them were prepared with a ten-year period of detailed analysis. In addition, analysts calculate company's future capital structure, which is used in WACC, in a completely different ways. These approaches depend on the corporation on behalf which the analysis was conducted.

The final conclusion is the same as in the research made by Głębocki et al. (2011). The general problem of valuations prepared in 2016 by domestic members of WSE is that they do not always present all relevant information, especially in the field of the valuation process. Parameters used in examined valuations, not always, but often do not have any justification. It is not uncommon to see a growth rate or a beta parameter without any comment on how it was estimated. Even the lack of information on few parameters is a huge drawback, which does not allow an investor to entirely follow and verify independently the analysis conducted. They allow to observe the results but not the whole way of thinking.

\section{References}

Adamczyk, P., Zbroszczyk, A. (2017). A key factor of the DCF model coherency. Journal of Economics and Management, 28, 5-22.

Aguirreamalloa, J., Avendaño, J.C., Fernandez, P. (2015). Market risk premium used in 82 countries in 2012: A survey with 7,192 answers. Retrieved from: https://papers.ssrn.com/sol3/papers.cfm?abstract_id=2084213 (22.05.2017).

Asquitha, P., Mikhail, M.B., Au, A.S. (2005). Information content of equity analyst reports. Journal of Financial Economics, 2 (75), 245-282.

Bancel, F., Mittoo, U.R. (2014). The gap between theory and practice of firm valuation: Survey of European valuation experts. Retrieved from: https://papers.ssrn.com/sol3/papers.cfm?abstract_id=2420380 (22.05.2017).

Copeland, T., Koller, T., Murrin, J. (1990). Valuation; Measuring and managing the value of companies. New York: John Wiley \& Sons.

Damodaran, A. (2012). Investment valuation. Tools and techniques for determining the value of any asset. New Jersey: John Wiley \& Sons.

Fernandez, P. (2015a). Betas used by professors: A survey with 2,500 answers. Retrieved from: https://papers.ssrn. com/sol3/papers.cfm?abstract_id=1407464 (22.05.2017). 
Fernandez, P. (2015b). Cash flow is a fact: Net income is just an opinion. Retrieved from: https://papers.ssrn.com/ sol3/papers.cfm?abstract_id=330540 (22.05.2017).

Fernandez, P. (2015c). Valuing Companies by Cash Flow Discounting: 10 methods and 9 theories. Retrieved from: https://papers.ssrn.com/sol3/papers.cfm?abstract_id=256987 (22.05.2017).

Głębocki, M., Grudziński, M., Kundera, M., Sylwestrzak, M. (2011). Studies of valuation methodology used in the stock exchange recommendations summary. Zeszyty Naukowe Uniwersytetu Szczecińskiego, 639, Finanse, Rynki Finansowe, Ubezpieczenia, 37, 575-588.

Graham, B., Dood, D. (1934). Security Analysis. New York: Whittlesey House, McGraw-Hill Book Co.

Mielcarz, P. (2015). Main features of recommendations and changes of share prices on WSE. Zeszyty Naukowe Uniwersytetu Szczecińskiego, 854, Finanse, Rynki Finansowe, Ubezpieczenia, 73, 707-719.

Mielcarz, P. (2016). Krótkookresowy wplyw rekomendacji na rynek giełdowy w Polsce. Warszawa: Wnydawnictwo Naukowe PWN.

Pinto, J.E., Henry, E., Robinson, T.R., Stowe, J.D. (2010). Equity asset valuation. New York: John Wiley \& Sons.

Pinto, J.E., Henry, E., Robinson, T.R., Stowe, J.D. (2015). Equity valuation: A survey of professional practice. Retrieved from: https://papers.ssrn.com/sol3/papers.cfm?abstract_id=2657717 (22.05.2017).

\section{WYCENA PRZEDSIĘBIORSTW - PRAKTYKA CZLONKÓW GPW W 2016 ROKU}

Streszczenie: $\mathrm{Cel}$ - Celem niniejszego artykułu jest weryfikacja popularności różnych metod wyceny przedsiębiorstw w praktyce domów maklerskich, jak również przedstawienie oraz omówienie statystyk parametrów użytych w procesie sporządzania wycen i rekomendacji wydawanych przez wybranych krajowych członków Giełdy Papierów Wartościowych w Warszawie (GPW) w roku 2016.

Metodologia badania - Badania bazują na 514 wycenach 118 przedsiębiorstw. Wyceny zostały pozyskane z 263 rekomendacji wydanych przez 8 krajowych członków GPW. Tak zebrane dane wejściowe zostały przetworzone przy użyciu metod statystycznych. Ich zagregowanie oraz porównane z literaturą przedmiotu oraz wcześniejszymi badaniami pozwoliło na sformułowanie finalnych wniosków.

Wynik - Na podstawie przeprowadzonej analizy autorzy ustalili, że szeroko rozpowszechniona opinia o wysokiej popularności metody DCF oraz metody porównawczej jest prawdziwa dla przebadanej zbiorowości. Co interesujące, wyniki agregacji wskazują, że praktycy często sporządzali wyceny przedsiębiorstw bazując na takich samych lub bardzo podobnych założeniach, co jest szczególnie widoczne w przyjmowanej długości okresu szczegółowej prognozy. Należy zauważyć, iż wyniki badań oparte są na danych historycznych, które nie odnoszą się do przyszłości oraz to, że dotyczą one jedynie wycen spółek notowanych na giełdzie papierów wartościowych.

Oryginalność/wartość - Autorzy dostarczają wiedzę na temat tego jak praktycy przekładają teorię wyceny przedsiębiorstw na praktykę, które metody używane są najczęściej oraz podejmują próbę objaśnienia tych zjawisk. Wiedza ta może stanowić podstawę do rewizji oraz ulepszenia narzędzi wyceny stosowanych w rekomendacjach giełdowych. Autorzy tym samym zachęcają do przeprowadzania dalszych dyskusji i badań w obszarze różnic pomiędzy praktyką a teorią wyceny przedsiębiorstw.

Słowa kluczowe: wycena przedsiębiorstw, praktyka wyceny przedsiębiorstw, GPW

\section{Citation}

Adamczyk, P., Zbroszczyk, A. (2017). Business Valuation - Practice of domestic WSE members in 2016. Finanse, Rynki Finansowe, Ubezpieczenia, 5 (89/2), 233-249. DOI: 10.18276/frfu.2017.89/2-17. 